\title{
Targeted acetylation of wood: a tool for tuning wood-water interactions
}

\author{
Ramūnas Digaitis (D) Emil E. Thybring (D) Lisbeth G. Thygesen (D) \\ Maria Fredriksson $(\mathbb{D}$
}

Received: 12 April 2021/Accepted: 17 June 2021 / Published online: 27 June 2021

(C) The Author(s) 2021

\begin{abstract}
Wood is an increasingly important material in the sustainable transition of societies worldwide. The performance of wood in structures is intimately tied to the presence of moisture in the material, which directly affects important characteristics such as dimensions and mechanical properties, and indirectly its susceptibility to fungal decomposition. By chemical modification, the durability of wood in outdoor environments can be improved by reducing the amount of moisture present. In this study, we refined a well-known chemical modification with acetic anhydride and showed how the spatial distribution of the modification of Norway spruce (Picea abies
\end{abstract}

Supplementary Information The online version contains supplementary material available at https://doi.org/10.1007/ s10570-021-04033-z.

R. Digaitis · M. Fredriksson ( $₫)$

Division of Building Materials, Department of Building and Environmental Technology, Lund University,

Box 118, 22100 Lund, Sweden

e-mail: maria.fredriksson@byggtek.lth.se

Present Address:

R. Digaitis

Biofilms - Research Center for Biointerfaces, Faculty of

Health and Society, Malmö University, Malmö, Sweden

E. E. Thybring · L. G. Thygesen

Bioresource Chemistry and Technology, Forest Nature and Biomass, Department of Geosciences and Natural Resource Management, University of Copenhagen,

Frederiksberg, Denmark
(L.) Karst.) could be controlled with the aim of altering the wood-water interactions differently in different parts of the wood structure. By controlling the reaction conditions of the acetylation it was possible to acetylate only the cell wall-lumen interface, or uniformly modify the whole cell wall to different degrees. The spatial distribution of the acetylation was visualised by confocal Raman microspectroscopy. The results showed that by this targeted acetylation procedure it was possible to independently alter the wood-water interactions in and outside of cell walls. The cell wall-lumen interface modification altered the interaction between the wood and the water in cell lumina without affecting the interaction with water in cell walls while the uniform modification affected both. This opens up a novel path for studying woodwater interactions in very moist environments and how moisture distribution within the wood affects its susceptibility towards fungal decomposition. 


\section{Graphic abstract}

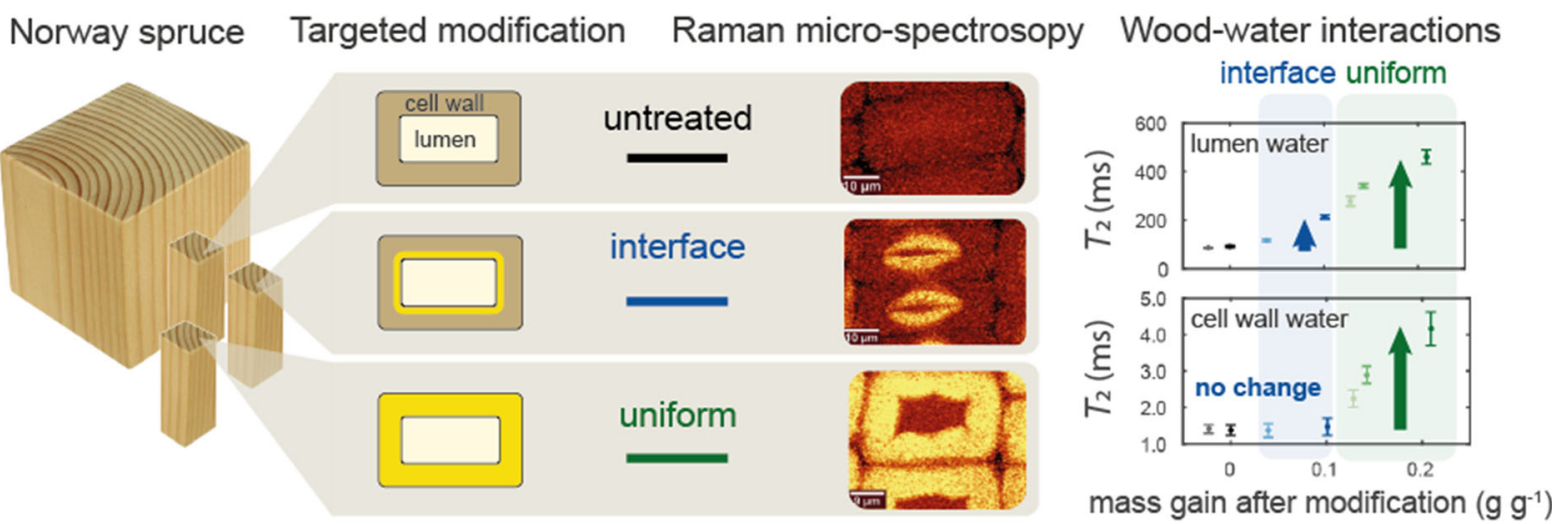

Keywords Low field nuclear magnetic resonance . Moisture · Raman microspectroscopy $\cdot$ Sorption · Wood modification

\section{Introduction}

Wood is an increasingly important material in the sustainable transition of societies worldwide. This is especially so in the construction sector, where replacing energy-intensive materials like concrete and steel with wood from sustainably managed forests can significantly lower the carbon footprint (Amiri et al. 2020; Churkina 2020). The performance of wood is intimately tied to the presence of moisture in the material, which affects important characteristics such as dimensions, mechanical properties, and durability. Wood consists of cells that were already dead in the living tree, where one of their main functions was to transport water. These cells have a central empty void called the lumen which is surrounded by cell walls that are intricate micrometer-scale composite structures made from hygroscopic biopolymers (i.e. cellulose, hemicelluloses and lignin). Water in wood can thus be present both within cell walls and as capillary water outside of cell walls. The water molecules within cell walls interact with the biopolymers by hydrogen bonding and water uptake here is accompanied by swelling (Engelund et al. 2013), creating pores on nano-meter scale (Hill et al. 2005). Water outside of cell walls is present in larger voids such as cell lumina and pit chambers where water uptake occurs by capillary condensation (Fredriksson 2019) or by capillary action if placed in contact with liquid water.

Achieving a long service life of wood in the construction sector is challenging in outdoor environments. In such environments, the material is exposed to occasional high levels of air humidity or directly to liquid water, e.g. rain or soil moisture. This creates favourable conditions for wood degradation either by decay fungi that require high levels of moisture (Rayner and Boddy 1988; Schmidt 2006) or by crack formation caused by deformations resulting from fluctuations in moisture content (Angst and Malo 2010; Chen et al. 2019). By chemical modification, the durability of wood in outdoor environments can be improved by increasing the resistance to fungal decay (Alfredsen et al. 2013, 2016; Beck et al. 2018a; Ringman et al. 2017) and limiting deformations (Ramsden et al. 1997; Rowell 2006). Key to improving durability is to reduce the amount of moisture present (Brischke and Alfredsen 2020; Ringman et al. 2019; Thybring 2013). Chemical modification covers a range of techniques for altering the wood chemistry. One of the most well-known chemical modifications of wood is acetylation by reaction with acetic anhydride (Fuchs 1928). To achieve penetration of the wood structure, the material is first impregnated with acetic anhydride and thereafter cured at elevated temperature. This causes a reaction with hydroxyl groups of the cell wall biopolymers whereby some of these are replaced by acetyl groups with acetic acid being formed as a by-product that needs subsequent removal (Mantanis 2017). Hereby acetylation reduces the number of hydroxyl groups (Beck et al. 2017; Popescu et al. 2014; Thybring et al. 2020b) that are the 
primary functional groups interacting with moisture in wood. Additionally, acetylation decreases the available space for moisture within the solid wood cell walls (Hill et al. 2005; Thybring et al. 2020b). As a result, acetylation reduces the cell wall moisture content (Beck et al. 2018b; Forsman et al. 2020; Hill et al. 2005; Himmel and Mai 2015; Passarini et al. 2017; Popescu et al. 2014; Thybring et al. 2020b; Thygesen et al. 2010; Yang et al. 2020).

In order to affect material properties, chemical modification needs to occur predominantly within the wood cell walls (Keplinger et al. 2015). However, the degradation of wood by decay fungi requires moisture conditions where capillary water is present in the porous wood structure (Ringman et al. 2014; Schmidt 2006; Zabel and Morell 1992). Acetylation of cell wall surfaces weakens the interaction energy between capillary water and wood (Beck et al. 2018b; Thygesen and Elder 2008; Thygesen et al. 2010; Yang et al. 2020) and changes the contact angle (Bryne and Wålinder 2010; Englund et al. 2009; Moghaddam et al. 2015). These changes will affect how moisture is taken up by acetylated wood through capillary action or capillary condensation at high air humidity. Acetylation will therefore affect moisture both within wood cell walls and in the capillary structure of wood, but how these changes relate to the improved resistance to fungal decay is still unknown. Understanding the effect of acetylation of moisture in different parts of the wood anatomy requires that the spatial distribution of acetylation is controlled. In the pioneering work of Keplinger et al. (2015), the spatial distribution of polystyrene anchored to wood hydroxyl groups was controlled in a two-step process. In the first step, the wood was methacrylated by reaction with either methacrylic anhydride or methacryloyl chloride. Because of differences in the reaction kinetics of these chemicals, wood cell walls were either methacrylated throughout by reaction with methacrylic anhydride or the methacrylation was limited to cell wall surfaces by reaction with methacryloyl chloride. In the second step, styrene was polymerised in-situ in the wood and reacting with the double bonds of the methacryl groups that hereby served as anchoring points.

In this study, we show how the spatial distribution of acetylation can be controlled in a one-step process by careful tuning of the reaction conditions. The aim of the applied modifications was to alter the wood- water interactions differently in different parts of the wood structure. The spatial distribution was documented by confocal Raman microspectroscopy by analysing a broad range of bond vibrations and wood water interactions were characterised with low-field nuclear magnetic resonance (LFNMR) relaxometry and sorption balance measurements. The study shows that this targeted acetylation process makes it possible to alter the wood-water interactions within and outside of cell walls independently. This opens up a novel path for tuning wood-water interactions in very moist environments allowing studies of the role of water in the resistance of wood to fungal decomposition in greater detail. Moreover, this study documents how confocal Raman microspectroscopy can be used to understand chemical modification processes better.

\section{Materials and methods}

Targeted chemical modification

Norway spruce (Picea abies (L.) Karst.) specimens with dimensions 10 (longitudinal) $\times 5 \times 5 \mathrm{~mm}^{3}$ were vacuum dried at $60{ }^{\circ} \mathrm{C}$ for a $24 \mathrm{~h}$ period prior to acetylation. Two acetylation protocols were performed with the aim to modify (1) the interface between cell walls and cell lumina and (2) the cell wall uniformly. A schematic overview of the modification procedure is given in Fig. 1 and the procedures are described in further detail below.

The uniform acetylation of spruce cell walls was achieved using a 1:4 (v/v) mixture of acetic anhydride (99.3\%, VWR Chemicals, Radnor, PA, USA) and pyridine (Sigma Aldrich, Merck KGaA, Darmstadt, Germany). Pyridine acts as a strong swelling agent on wood (Mantanis et al. 1994). Specimens dried in a vacuum oven at $60{ }^{\circ} \mathrm{C}$ for $24 \mathrm{~h}$ were placed in roundbottom glass flasks each equipped with a rubber injection septum. Vacuum (about $10^{-2}$ mbar) was applied and maintained for $20 \mathrm{~min}$ before the reagent mixture was injected through the rubber septum. Nitrogen gas was used to re-establish atmospheric pressure in the round bottom flasks which were then capped with glass stoppers. Using a heated oil-bath, the reaction was carried out at $80{ }^{\circ} \mathrm{C}$ for three different reaction times, $20 \mathrm{~min}, 1$ and $3 \mathrm{~h}$ to achieve three degrees of modification (Table 1). Both the bath and the contents in the flasks were stirred. To facilitate an 


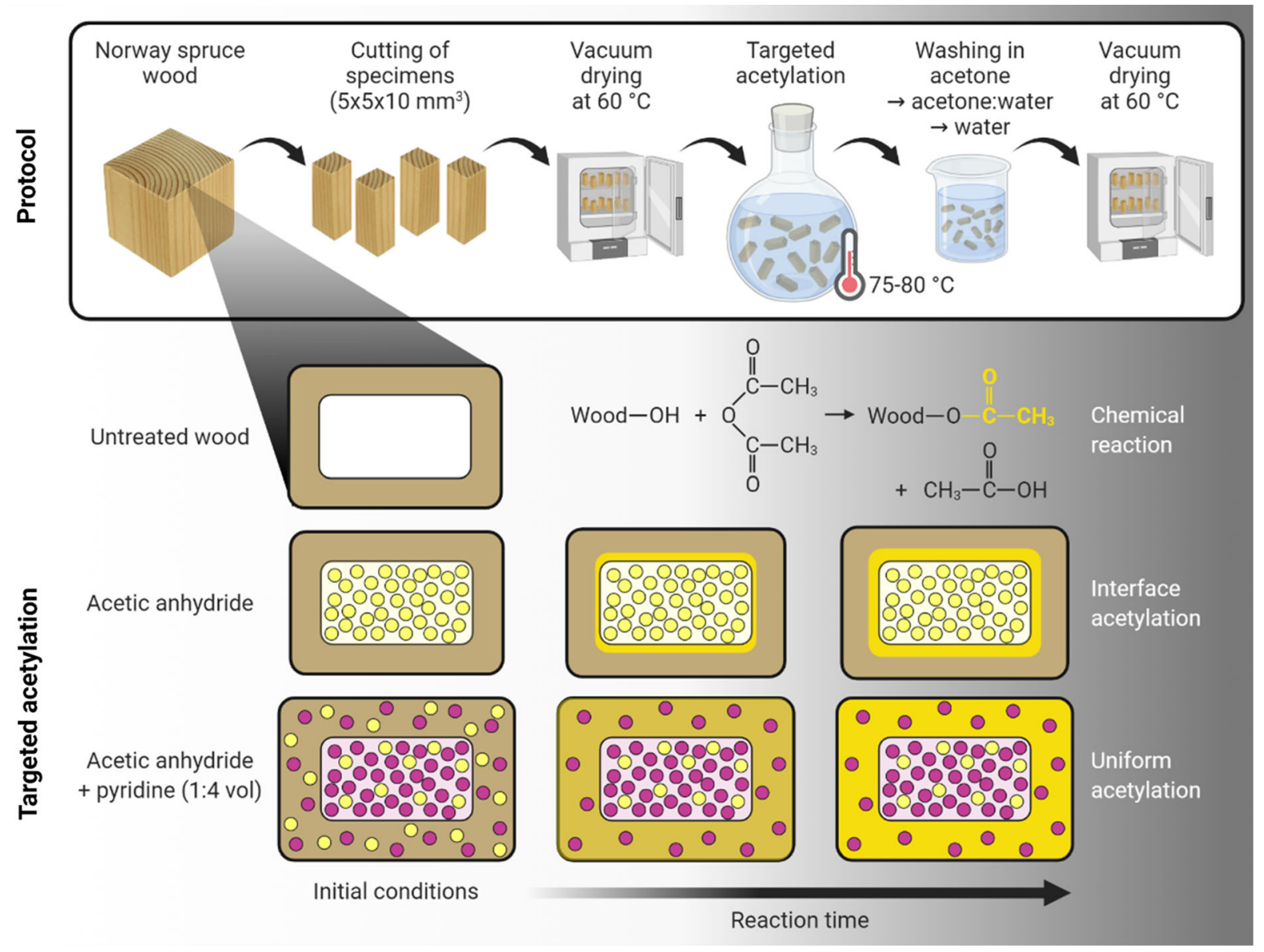

Fig. 1 Overview of the modification procedure. Acetic anhydride, represented by yellow spheres, facilitated acetylation of lumen interfaces; while pyridine, represented by purple spheres, induced swelling, and hereby facilitated diffusion of acetic anhydride and uniform acetylation of wood cell walls

Table 1 Overview of modification protocols and average relative mass change, $R_{\text {mod }}$, of specimens. For the interface modification, where individual masses were taken for all specimens, the standard deviations are shown in brackets

\begin{tabular}{lllll}
\hline Name & Modification type & Time & Temperature $\left({ }^{\circ} \mathrm{C}\right)$ & $R_{\text {mod }}\left(\mathrm{g} \mathrm{g}^{-1}\right)$ \\
\hline Untreated & - & - & - & - \\
Pyridine & Pyridine controls & $3 \mathrm{~h}$ & 80 & -0.023 \\
Uniform A & $1: 4$ acetic anhydride:pyridine & $20 \mathrm{~min}$ & 80 & 0.128 \\
Uniform B & $1: 4$ acetic anhydride:pyridine & $1 \mathrm{~h}$ & 80 & 0.142 \\
Uniform C & $1: 4$ acetic anhydride:pyridine & $3 \mathrm{~h}$ & 0.209 \\
Interface 1 & Acetic anhydride & $5 \mathrm{~h}$ & $0.034(0.006)$ \\
Interface 2 & Acetic anhydride & $24 \mathrm{~h}$ & 75 & $0.099(0.007)$ \\
\hline
\end{tabular}

even distribution of reagents, the specimens were left to soak in the reagent mixture prior to heating in the oil-bath. These soaking times were approximately $2 \mathrm{~h}$ for the specimens reacted for 20 min, approximately $1 \mathrm{~h}$ for the specimens reacted for $1 \mathrm{~h}$, and approximately $30 \mathrm{~min}$ for the specimens reacted for $3 \mathrm{~h}$. 
To modify the interface between cell walls and cell lumina, a solution of pure acetic anhydride was used, and the reaction was carried out at $75{ }^{\circ} \mathrm{C}$. The same protocol for impregnation and heating as for the uniform acetylation was followed. Two reaction times, 5 and $24 \mathrm{~h}$ were used to achieve two degrees of modification (Table 1). After impregnation the round bottom flasks were directly transferred to the oil-bath.

Both types of acetylation reactions were carried out in batches, each consisting of 60 specimens. Independent of the treatment, $10 \mathrm{~g}$ of reagent solution was used for each $\mathrm{g}$ of wood. In addition, control specimens were treated with pure pyridine at $80{ }^{\circ} \mathrm{C}$ for $3 \mathrm{~h}$ hours.

After the defined reaction period (Table 1), the flasks were removed from the oil-bath and the reaction was stopped by decanting the hot reagent and applying ice-cold acetone ( $20 \mathrm{~g}$ for each $\mathrm{g}$ of wood). Residual chemicals were eventually removed by first washing wood specimens in pure acetone (two washing cycles of $20 \mathrm{~min}$ ), then in 1:1 v/v solution of acetone and water (two cycles of $20 \mathrm{~min}$ ) and finally in ultra-pure water (two cycles of $24 \mathrm{~h}$ ). In order to accelerate the washing process, the washing solution with the specimens was agitated with a magnetic stirrer. Finally, all specimens were dried at $60{ }^{\circ} \mathrm{C}$ for $24 \mathrm{~h}$ under vacuum.

The mass change caused by each modification was evaluated as the relative mass change, $R_{\text {mod }}$ :

$R_{\mathrm{mod}}=\frac{m_{\mathrm{dry}}-m_{\mathrm{dry}, 0}}{m_{\mathrm{dry}, 0}}$

where $m_{\text {dry }}(\mathrm{g})$ is the dry mass after modification and $m_{\text {dry }, 0}(\mathrm{~g})$ is the dry mass before the modification. For the interface acetylations, the individual dry mass of each specimen was recorded after vacuum drying at $60{ }^{\circ} \mathrm{C}$ for $24 \mathrm{~h}$ before and after the modification. The average mass change as well as the standard deviation is given in Table 1. For the uniform acetylations and the pyridine controls, the change in dry mass of the whole batch was determined before and after modification and the $R_{\text {mod }}$ for these modification are therefore given without standard deviations in Table 1. However, to get a sense of the spread in mass change also for these batches, the individual mass changes of ten specimens from each modification intensity (A, B and C) were recorded. The standard deviation between these ten specimens ranged between 0.12 and $0.17 \%$ for the different modifications.

The pyridine treatment gave a small mass loss (Table 1) in the same range as found by Hill et al. (1998) which possibly is due to extraction of the extractives within the wood.

Spatial distribution of chemical changes using Raman microspectroscopy

Wood cross-sections with a thickness of $20-25 \mu \mathrm{m}$ were cut from untreated and modified specimens using a rotary microtome (RM2255, LEICA, Germany). The cross-sections were placed on a glass slide with a small water droplet, covered with a coverslip, which was sealed with nail polish. A confocal Raman microscope (alpha300R, WITec, Ulm, Germany) equipped with a $532 \mathrm{~nm}$ laser and an oil immersion objective (100x) was used to identify the extent and location of the acetylation in wood. The laser power used for sample excitation was $20 \mathrm{~mW}$ and the integration time was $0.1 \mathrm{~s}$. Since the Raman intensity of the cellulose bands depends on the angle between the orientation of the cellulose microfibrils in the cell walls and the laser polarization direction (Gierlinger et al. 2013), all cross-sections were aligned in the same way prior to the acquisition of Raman spectra. A single crosssection from each modification was selected for Raman microscopy and 4 to 6 area scans were acquired from each cross-section. Area scans were obtained with a spatial resolution of approximately $0.3 \mu \mathrm{m}$.

Raman microscopy data processing was performed using the software Project Five Plus (WITec, Ulm, Germany). A cosmic ray removal filter was applied and spectra were baseline corrected and smoothened using the Savitzky-Golay algorithm (windows size: 8, order of polynomial: 4). The average Raman spectrum from each image was then obtained to analyse spectral changes introduced by the modifications. The Raman spectra of native and modified wood cell walls are complex and comprise many different as well as overlapping peaks, which are signatures of the molecular groups and bonds within the polymeric cell wall constituents. Especially cellulose and hemicelluloses have overlapping signals. To facilitate comparison between the different treatments the average spectra were normalized to the aromatic lignin 
stretching vibration at $1600 \mathrm{~cm}^{-1}$ according to Gierlinger et al. (2013). From the average Raman spectra, it was found that intensities of the peaks at approximately 2941, 1735, 910 and $645 \mathrm{~cm}^{-1}$ increased substantially. The assignment of these peaks together with the most prominent Raman peaks detected in native and modified wood is provided in Table S1.

To visualize the spatial distribution of the introduced chemical components in wood, images were generated by evaluating Raman signal intensities of the aforementioned Raman bands using integrated intensity (sum) filters. The precise peak boundaries used for calculations were 2916-2966, 1700-1760, 885-935 and 619-689 $\mathrm{cm}^{-1}$. The intensity of the $\mathrm{OH}$ stretching at approximately $3387 \mathrm{~cm}^{-1}$ was also significantly affected by the modifications and the region between $3098-3676 \mathrm{~cm}^{-1}$ was used to calculate its spatial distribution in wood. In addition, spatial distribution of lignin was determined in order to better indicate boundaries between neighbouring cells (integration range: $1570-1685 \mathrm{~cm}^{-1}$ ). The intensity scale is the same for all images pertaining to the same bond.

The acetylation profiles across specific cell wall areas were analysed in greater detail by evaluating the average intensity of the Raman signals associated with acetylation over $3 \mu \mathrm{m}$ wide cross sections. The positions of middle lamellas (ML) and lumina along the specific cell wall sections were estimated visually based on the Raman images of lignin signal (integration range: $1570-1685 \mathrm{~cm}^{-1}$ ) at the centre of the $3 \mu \mathrm{m}$ wide band shown in the 3D Raman images.

Data analysis by use of MCR-ALS (Multivariate Curve Resolution, Alternating Least Squares) was initially attempted, but in the end abandoned, as signals from acetylation and from lignin could not be sufficiently unmixed.

\section{Wood-water interactions}

\section{Location and state of water}

The influence of acetylation on the interaction between wood and water was studied using LFNMR relaxometry. Five specimens of each sample type were initially vacuum saturated with water. For this, specimens were placed in round-bottom glass flasks equipped with rubber injection septum, vacuum (about $10^{-2}$ mbar) was maintained for $20 \mathrm{~min}$ prior to injection of MilliQ water through the rubber septum. Finally, atmospheric pressure was re-established.

Before LFNMR measurement, each specimen was wiped off using a moist cloth (Wettex, Freudenberg Household Products, Norrköping, Sweden) to remove free water from its surface, but without drying the specimen. The specimen was then placed in a preweighed NMR tube with a Teflon rod, which both sealed the tube and filled the air space above the specimen and thus limited evaporation. The tube with the specimen and the rod was then weighed again to obtain the vacuum saturated mass of the specimen. The sealed tube was then placed in a LFNMR instrument (Bruker mq20-Minispec, Bruker, Billerica, MA, USA) with a 0.47 Tesla permanent magnet in such a way that the specimen orientation was the same for all measurements. The probe temperature of the LFNMR instrument was maintained at $21 \pm 0.5{ }^{\circ} \mathrm{C}$ by a water-cooling system, and each sample was allowed to equilibrate to the instrument temperature for $5 \mathrm{~min}$ before measurement. The spin-spin relaxation time $\left(T_{2}\right)$ was determined using the Carr-PurcellMeiboom-Gill (CPMG) pulse sequence with a pulse separation $(\tau)$ of $0.1 \mathrm{~ms}, 16000$ echoes, 32 scans and a recycle delay of $5 \mathrm{~s}$. The gain was set individually for each specimen and ranged between 80 and $82 \mathrm{~dB}$.

The $T_{2}$ decay curves were analysed by multiexponential decay analysis, which fits a large number of exponential decay functions to the experimentally obtained curve (Istratov and Vyvenko 1999). Each decay function is described by a characteristic time constant (relaxation time) and a pre-exponential coefficient. In this study, 200 decay functions were fitted with pre-defined, logarithmically spaced time constants that covered the time period from the first to last data point, i.e. $0.2 \mathrm{~ms}$ to $3.3 \mathrm{~s}$. Fitting is performed with the non-negative least squares algorithm of Lawson and Hanson (1974) to minimize the statistic

$$
\begin{aligned}
\chi^{2}= & \sum_{i=1}^{m}\left(E_{\mathrm{i}}-\sum_{n=1}^{N} A_{n} \exp \left(\frac{-t_{\mathrm{i}}}{\tau_{n}}\right)\right)^{2} \\
& +\frac{1}{\alpha} \sum_{n=1}^{N-2}\left(2 A_{n+1}-A_{n}-A_{n+2}\right)^{2}
\end{aligned}
$$

where $m$ is the number of data points (16 000 echoes), $E_{i}$ and $t_{i}$ are the experimental signal and time, respectively, of the $i^{\text {th }}$ data point, $N$ is the number of fitted exponential decay functions (200), $A_{n}$ and $\tau_{n}$ are 
the pre-exponential coefficient and time constant, respectively, of the $n^{\text {th }}$ decay function, and $\alpha$ is a regularisation parameter that controls the difference between adjacent $A_{n}$. The result of the analysis can be plotted as a spectrum of pre-exponential coefficients on a logarithmic scale of time constants. Typically, decay curves from LFNMR measurements on water in wood can be described by a limited number of decay functions (Araujo et al. 1992; Beck et al. 2018b; Fredriksson and Thygesen 2017). These will appear in the spectrum as peaks with a characteristic time constant at their apex. The width of the peaks and the general smoothness of the spectrum depend on the value of the regularisation parameter $\alpha$. If it is too low the spectrum is smooth and individual peaks cannot be resolved, whereas a too high value of $\alpha$ will result in a spiky spectrum with multiple small peaks arising from noise in the signal. Finding an appropriate value of $\alpha$ is therefore important, but it is not a trivial task (Istratov and Vyvenko 1999). A common strategy is to select a value around the threshold between the smooth and spiky domains, which can be found from a plot of $\chi^{2}$ versus $\alpha$. In this study, a value of $10^{9}$ was selected for all samples.

The amount of information that can be extracted from decay curves by multi-exponential decay analysis is limited by the inherent noise in the data. Thus, the analysis can only resolve peaks with characteristic time constants that are spaced farther apart than the resolution limit. This in turn is defined as a ratio of the time constants and depends on the signal-to-noise as (Bertero et al. 1982):

$\delta=\frac{\tau_{i}}{\tau_{i+1}}=\exp \left[\frac{\pi^{2}}{\operatorname{arcosh}\left(\pi\left(\frac{E}{\varepsilon}\right)^{2}\right)}\right]$

where $\delta$ is the resolution limit, i.e. the minimum spacing between two adjacent time constants, $\tau_{i}$ and $\tau_{i+1}$ with $\tau_{i}>\tau_{i+1}$, and $E / \varepsilon$ is the signal-to-noise ratio. In this study, $E / \varepsilon$ was determined by the ratio of the initial signal $E_{1}$ in the time series to the standard deviation of the signal in the last $500 \mathrm{~ms}$ for each decay curve. The signal-to-noise varied in the range 357-533, which corresponds with a resolution limit $\delta$ of 1.99-2.07. The spectra for all samples in this study had peaks with characteristic time constants spaced farther apart than the resolution limit.
Based on these continuous $T_{2}$ distributions, the influence of the modifications on water in different locations within the wood structure was evaluated. Since the $T_{2}$ is related to the physical environment (surface-to-volume ratio of pores) (Menon et al. 1987) water within cell walls can be separated from water outside of cell walls and capillary water in differently sized voids within the wood structure can be distinguished (Almeida et al. 2007; Araujo et al. 1992; Fredriksson and Thygesen 2017; Labbé et al. 2006; Thygesen and Elder 2008). The $T_{2}$ at the maximum intensity of each peak was evaluated, and in those cases where a certain water population was represented by more than one peak (e.g. water in small macro voids), the $T_{2}$ was calculated as the exponentially weighted average of the $T_{2}$ of the individual peaks. The moisture content represented by each peak, $\omega_{i}$, was evaluated as (Telkki et al. 2013):

$\omega_{i}=\omega_{\mathrm{tot}} \frac{S_{i}}{S_{\mathrm{tot}}}$

where $S_{i}(-)$ is the sum of pre-exponential coefficients related to peak $i, S_{\text {tot }}(-)$ is the sum of all preexponential coefficients in the spectrum, and $\omega_{\text {tot }}$ $\left(\mathrm{g} \mathrm{g}^{-1}\right)$ is the total moisture content of the wood specimen determined as:

$\omega_{\mathrm{tot}}=\frac{m_{\mathrm{vac}}-m_{\mathrm{dry}}}{m_{\mathrm{dry}, 0}}$

where $m_{\mathrm{vac}}(\mathrm{g})$ is the vacuum saturated mass after modification, $m_{\text {dry }}(\mathrm{g})$ is the dry mass after modification and $m_{\mathrm{dry}, 0}(\mathrm{~g})$ is the dry mass before modification which can be calculated from:

$m_{\mathrm{dry}, 0}=\frac{m_{\mathrm{dry}}}{1+R_{\mathrm{mod}}}$

For the uniform modifications, the average mass increase given in Table 1 was used. However, for the interface modifications, $R_{\text {mod }}$ values for the individual specimens were available and used instead (see Table S2). The moisture content was thus always based on the dry mass before modification, $m_{\mathrm{dry}, 0}$, which enabled comparison between specimens. Note that no correction was made for the pyridine controls where a mass loss was seen. The assignment of peaks to cell wall water was consistently made including only the peak with the shortest $T_{2}$, except for uniform modification $\mathrm{C}$ where this peak was split in two for two specimens (see Figure S9). The peak with the longest 
$T_{2}$ was assigned to water in cell lumina and all small peaks between the cell wall water peak and the peak representing water in cell lumina were assigned to water in small macro voids.

\section{Moisture exclusion efficiency in the hygroscopic moisture range}

The efficiency of acetylation in reducing the cell wall moisture content was evaluated in the hygroscopic moisture range using two sorption balances (DVS Advantage, Surface Measurement Systems Ltd., London, UK) which monitor the mass of a sample with a resolution of $0.1 \mu \mathrm{g}$ and where different relative humidity $(\mathrm{RH})$ levels are generated by mixing dry and water saturated nitrogen gas (see e.g. Williams (1995)). One specimen $\left(5 \times 5 \times 10 \mathrm{~mm}^{3}\right)$ of each specimen type (Table 1) was vacuum saturated with deionised water. Before each measurement, a sample was prepared by cutting thin pieces with a razor blade from one on these specimens. Excess water was removed on a moist cloth before placing the pieces in the sample pan. For each measurement, the vacuum saturated sample was exposed to the following $\mathrm{RH}$ levels: $95,80,65,50,35,0,35,50,65,80$, and 95\%, i.e. both desorption and absorption isotherms were measured. The change between RH levels was automated using the following predefined hold times: at 35,50 and $65 \% \mathrm{RH}$ was $12 \mathrm{~h}$, the duration at $80 \%$ was $24 \mathrm{~h}$ while the duration at $95 \% \mathrm{RH}$ was $60 \mathrm{~h}$ in desorption and $24 \mathrm{~h}$ in absorption. The total duration of one measurement was thus 10 days. At the end of each measurement, the sample was dried at $60{ }^{\circ} \mathrm{C}$ and $0 \% \mathrm{RH}$ for $8 \mathrm{~h}$ using the built-in preheater with succeeding temperature stabilisation at $20{ }^{\circ} \mathrm{C}$ and $0 \%$ $\mathrm{RH}$ for $2 \mathrm{~h}$ before the dry mass was taken. The dry masses of each sample ranged between 7 and $11 \mathrm{mg}$. Predefined hold times were selected instead of a mass stability criterion, which is commonly used, because of uncertainties with the latter (Glass et al. 2018, 2017). However, if the sorption kinetics is different for different sample types this could give apparent differences between sample types since they have equilibrated to different extents. Therefore, the degree of equilibrium at each RH step was evaluated as the change in moisture content over time $(d \omega / d t)$ for the last two hours at each step (Table 2). According to Glass et al. (2018), $d \omega / d t<3 \mu \mathrm{g} \mathrm{g}^{-1} \mathrm{~min}^{-1}$ calculated over two hours gives an average error in moisture content of less than $0.003 \mathrm{~g} \mathrm{~g}^{-1}$. As seen in Table 2, the errors in equilibrium moisture content caused by lack of equilibrium should thus be small in this study. Also, the difference in degree of equilibrium was rather between absorption and desorption than between sample types.

The equilibrium moisture content at each RH level was evaluated using Eq. 5, but with the equilibrium mass at each RH level instead of the vacuum saturated mass. Note that the masses were corrected for the mass gain obtained by the modification (Table 1) so that all moisture contents were based on dry mass before modification, $m_{\mathrm{dry}, 0}$, in order to enable comparison of moisture contents between specimen types. Otherwise, the increased dry mass obtained by the modification would give a seemingly higher reduction in moisture content than what was actually the case. The mass increase of the individual specimen was used for the interface modification (Table S2) while the average of the whole batch was used for the uniformly modified specimens (Table 1). Note that no correction was made for the pyridine controls where a mass loss was seen. From these moisture contents, the moisture exclusion efficiency was determined as:

$\xi_{\omega}=\frac{\omega_{\mathrm{untr}}-\omega_{\mathrm{mod}}}{\omega_{\mathrm{untr}}}$

where $\xi_{\omega}(-)$ is the moisture exclusion efficiency, $\omega_{\bmod }$ $\left(\mathrm{g} \mathrm{g}^{-1}\right)$ is the equilibrium moisture content of the modified wood material (or pyridine controls) at a certain relative humidity level, and $\omega_{\text {untr }}\left(\mathrm{g} \mathrm{g}^{-1}\right)$ is the equilibrium moisture content of the untreated material at the same relative humidity level. These moisture contents were, as previously described, also based on the dry mass before modification, $m_{\mathrm{dry}, 0}$.

\section{Hydroxyl accessibility}

The hydroxyl accessibility was determined by deuterium exchange in a sorption balance (DVS Advantage, Surface Measurement Systems Ltd., London, UK). These measurements were made both for earlywood and latewood separately and for samples consisting of both earlywood and latewood. A sample corresponding to a dry mass in the range of 8-11 mg was prepared by cutting thin pieces from a $5 \times 5 \times 10 \mathrm{~mm}^{3}$ specimen using a razor blade. For the measurements where both earlywood and latewood were included, five replicates were used and for 
Table 2 Degree of equilibrium at the different $\mathrm{RH}$ levels expressed as $d \omega / d t$ in $\mu \mathrm{g} \mathrm{g}^{-1} \mathrm{~min}^{-1}$. Note that the values at $0 \%$ $\mathrm{RH}$ is for the $0 \% \mathrm{RH}$ step between desorption and absorption while the dry mass used to calculate the moisture content was determined by drying at elevated temperature (see method description in the text for details)

\begin{tabular}{|c|c|c|c|c|c|c|c|c|c|c|c|}
\hline \multirow[t]{2}{*}{ RH } & \multicolumn{6}{|c|}{ Desorption } & \multicolumn{5}{|c|}{ Absorption } \\
\hline & $95 \%$ & $80 \%$ & $65 \%$ & $50 \%$ & $35 \%$ & $0 \%$ & $35 \%$ & $50 \%$ & $65 \%$ & $80 \%$ & $95 \%$ \\
\hline Pyridine controls & 5.4 & 2.4 & 3.8 & 3.6 & 3.5 & 0.4 & 0.9 & 2.8 & 0.0 & 0.6 & 2.3 \\
\hline Untreated & 3.4 & 2.4 & 3.9 & 3.7 & 2.8 & 0.2 & 0.4 & 1.1 & 1.8 & 0.6 & 2.1 \\
\hline Interface mod. 1 & 1.2 & 2.6 & 4.2 & 3.3 & 2.6 & 0.2 & 0.4 & 0.9 & 1.5 & 0.7 & 1.5 \\
\hline Interface mod. 2 & 2.0 & 2.5 & 4.0 & 3.2 & 2.3 & 0.2 & 0.2 & 1.1 & 1.6 & 0.9 & 1.2 \\
\hline Uniform mod. A & 0.7 & 2.9 & 4.8 & 3.2 & 2.5 & 0.1 & 0.2 & 1.4 & 1.3 & 1.5 & 1.7 \\
\hline Uniform mod. B & 0.8 & 3.5 & 3.9 & 2.5 & 1.9 & 0.1 & 0.2 & 0.8 & 1.3 & 1.8 & 2.1 \\
\hline Uniform mod. C & 1.1 & 2.8 & 4.2 & 2.7 & 1.7 & 0.1 & 0.1 & 0.7 & 1.4 & 1.7 & 1.2 \\
\hline
\end{tabular}

the measurements which were made on earlywood and latewood separately, 4 replicates were used. In total, measurements were thus made on 91 samples. Each measurement was performed as follows: the sample was placed in the sorption balance and was dried at $60{ }^{\circ} \mathrm{C}$ and $0 \% \mathrm{RH}$ for $6 \mathrm{~h}$ using the preheater in the instrument. Ramps of $10 \mathrm{~min}$ were used to increase/ decrease the temperature to/from $60{ }^{\circ} \mathrm{C}$. After drying, an additional $2 \mathrm{~h}$ period of temperature stabilisation at $20{ }^{\circ} \mathrm{C}$ and $0 \% \mathrm{RH}$ followed. The sample was then exposed to deuterium oxide vapour (95\% RH) for $10 \mathrm{~h}$ after which the sample was again dried using the same procedure as for the initial drying. Since the exposure to deuterium oxide vapour causes an exchange from hydrogen to deuterium for the accessible hydroxyl groups, the mass obtained after the second drying is higher than the initially determined dry mass. From this change in dry mass the hydroxyl accessibility was determined by (Thybring et al. 2020b):

$c_{\text {acc }}=\frac{\Delta m_{\mathrm{dry}}}{\Delta M_{\text {hydrogen }} m_{\text {dry }}\left(1+R_{\text {mod }}\right)}$

where $c_{\text {acc }}\left(\mathrm{mol} \mathrm{g}^{-1}\right)$ is the hydroxyl accessibility, $\Delta m_{\text {dry }}(\mathrm{g})$ is the difference in dry mass before and after deuteration, $\Delta M_{\text {hydrogen }}\left(\mathrm{g} \mathrm{mol}^{-1}\right)$ is molar mass difference $\left(1.006 \mathrm{~g} \mathrm{~mol}^{-1}\right)$ between deuterium $\left({ }^{2} \mathrm{H}\right.$ or D) and protium $\left({ }^{1} \mathrm{H}\right)$, and $m_{\text {dry }}(\mathrm{g})$ is the dry mass and $R_{\text {mod }}\left(\mathrm{g} \mathrm{g}^{-1}\right)$ is the mass increase caused by the modification (Table 1 ). The correction of the dry mass by $\left(1+R_{\text {mod }}\right)$ was used to enable comparison between specimen types. In this way, the hydroxyl accessibility is related to the dry mass before modification, $m_{0, \mathrm{dry}}$, for all specimen types. Here, the average mass increase after modification was taken for all modifications. No correction was, however, made for mass loss of the pyridine controls.

\section{Results}

Chemical changes

In Fig. 2, the average Raman spectra normalised to the aromatic lignin stretching vibration at $1600 \mathrm{~cm}^{-1}$ are shown. Acetylation resulted in Raman spectral changes, where in particular the intensity of the peaks at approximately $1735 \mathrm{~cm}^{-1}, 2941 \mathrm{~cm}^{-1}, 645 \mathrm{~cm}^{-1}$ and $910 \mathrm{~cm}^{-1}$ increased substantially (Fig. 2). These peaks were assigned to $1735 \mathrm{~cm}^{-1}$ : $\mathrm{C}=\mathrm{O}$ carbonyl stretching vibration (Adebajo et al. 2006), $2941 \mathrm{~cm}^{-1}$ : C-H stretching vibrations (Bock and Gierlinger 2019), $645 \mathrm{~cm}^{-1}$ : $\mathrm{O}-\mathrm{C}=\mathrm{O}$ in-plane deformation (tentative, $655 \mathrm{~cm}^{-1}$ (Adebajo et al. 2006), and $910 \mathrm{~cm}^{-1}$ : HCC and HCO bending (Wiley and Atalla 1987), see Table S1. The Raman signal at $2941 \mathrm{~cm}^{-1}$ had a pronounced intensity in wood also prior to the modification since the methoxy group is abundant in lignin (Fig. 2). Also, since Raman imaging was carried out on wood entirely submerged in water, the broad spectral band at approximately $3387 \mathrm{~cm}^{-1}$ (corresponding to $\mathrm{OH}$ stretching (Wiley and Atalla 1987)) mostly originates from water rather than from wood polymers.

By lowering the acetylation reaction temperature and avoiding the use of a swelling agent it was possible to preferentially acetylate the cell wall-lumen 

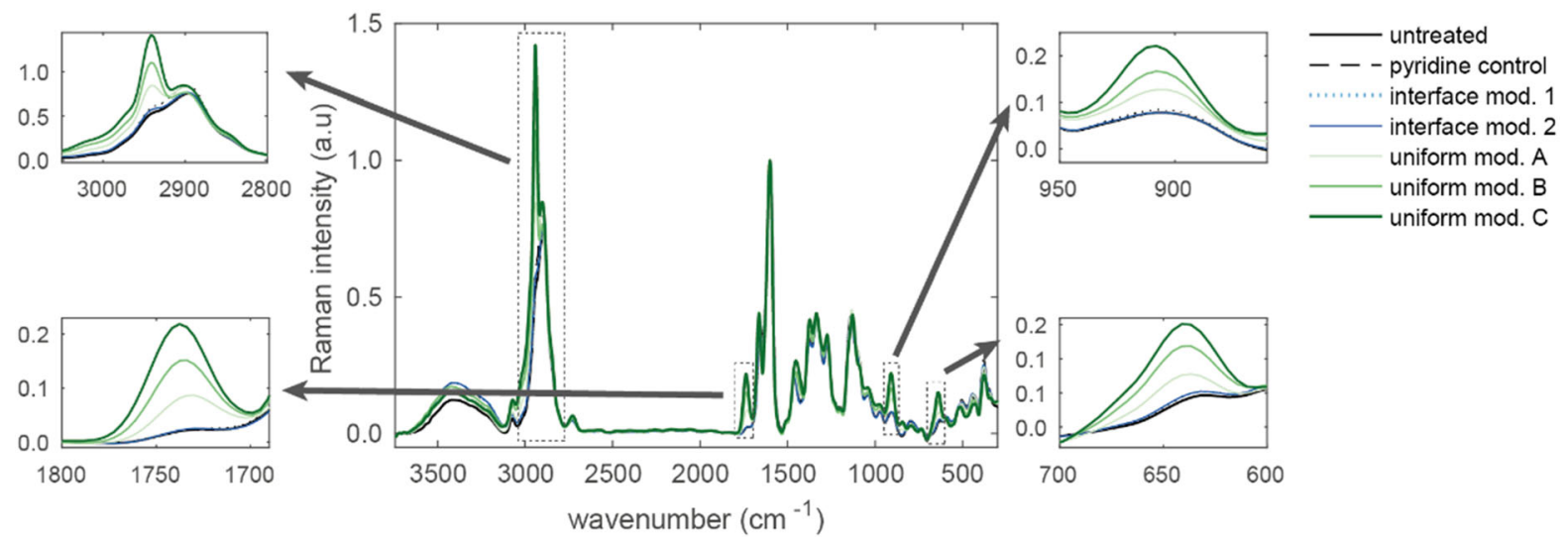

Fig. 2 Average Raman spectra of untreated, pyridine treated and acetylated spruce normalised to the aromatic lignin stretching vibration at $1600 \mathrm{~cm}^{-1}$

interfaces and the penetration depth could be controlled by adjusting the reaction time. This is illustrated in Fig. 3, which shows how lignin, acetylation and hydroxyl groups are distributed across the latewood and earlywood cell walls of untreated as well as the differently modified wood. Since sample preparation and spectral acquisition were strictly standardised, these signals can be used semi-quantitatively for comparison also between images, i.e. with caution comparison can be done between images in the same column, but not between images in the same row. In addition, Fig. 4 and Figure S8 show how acetylation, lignin and $\mathrm{OH}$ groups are distributed across different cell wall regions for the interface modification of the highest intensity (interface modification 2). Furthermore, the uniform modification procedure (including a swelling agent) was successful and an increased reaction time generally gave increasing degree of uniform modification of cell walls (Fig. 3).

\section{Wood-water interactions}

The uniform and interface modifications affected the interaction with water in cell walls differently. For the interface modifications, no change in $T_{2}$ for cell wall water was seen (Fig. 6c and left peak(s) in Fig. 5). However, clear changes in $T_{2}$ for peaks representing capillary water were observed for all modifications (Fig. 6d and right peak in Fig. 5); the higher intensity of the modification, the longer $T_{2}$ for capillary water in small macro voids as well as in cell lumina. In terms of $T_{2}$, the interface modification did thus not affect the interaction between the water and cell walls, but affected the interaction between the wood and capillary water. The uniform modification on the other hand, affected the interaction with both water in cell walls and capillary water (Fig. 5, Fig. 6c,d). Also, increasing intensity of the modification gave increasing $T_{2}$ (Fig. 5, Fig. 6c, d).

Regarding the cell wall moisture content, the results indicate that the interface modification of the lowest degree did not change the cell wall moisture content in the water-saturated state, but it was reduced for the interface modification of the highest degree (Fig. 6a). However, in the hygroscopic range, a small reduction in moisture content (increase in moisture exclusion efficiency) was seen also for the interface modification of the lowest degree (Fig. 7b). For the uniform modifications, the cell wall moisture content decreased with increasing modification intensity (Fig. 6a).

The hydroxyl accessibility decreased with increasing modification intensity for all modifications (Fig. 7a). However, for untreated as well as modified specimens, the hydroxyl accessibility was higher in latewood than in earlywood (Fig. 7a).

\section{Discussion}

Selective imaging of the Raman peaks at 1735, 2941, 645 and $910 \mathrm{~cm}^{-1}$ showed that acetylation with pure acetic anhydride allowed targeted acetylation of cell wall-lumen interfaces. The lowest degree of interface modification, seen as an oval band at the cell walllumen interface had a width of approximately $2 \mu \mathrm{m}$ 


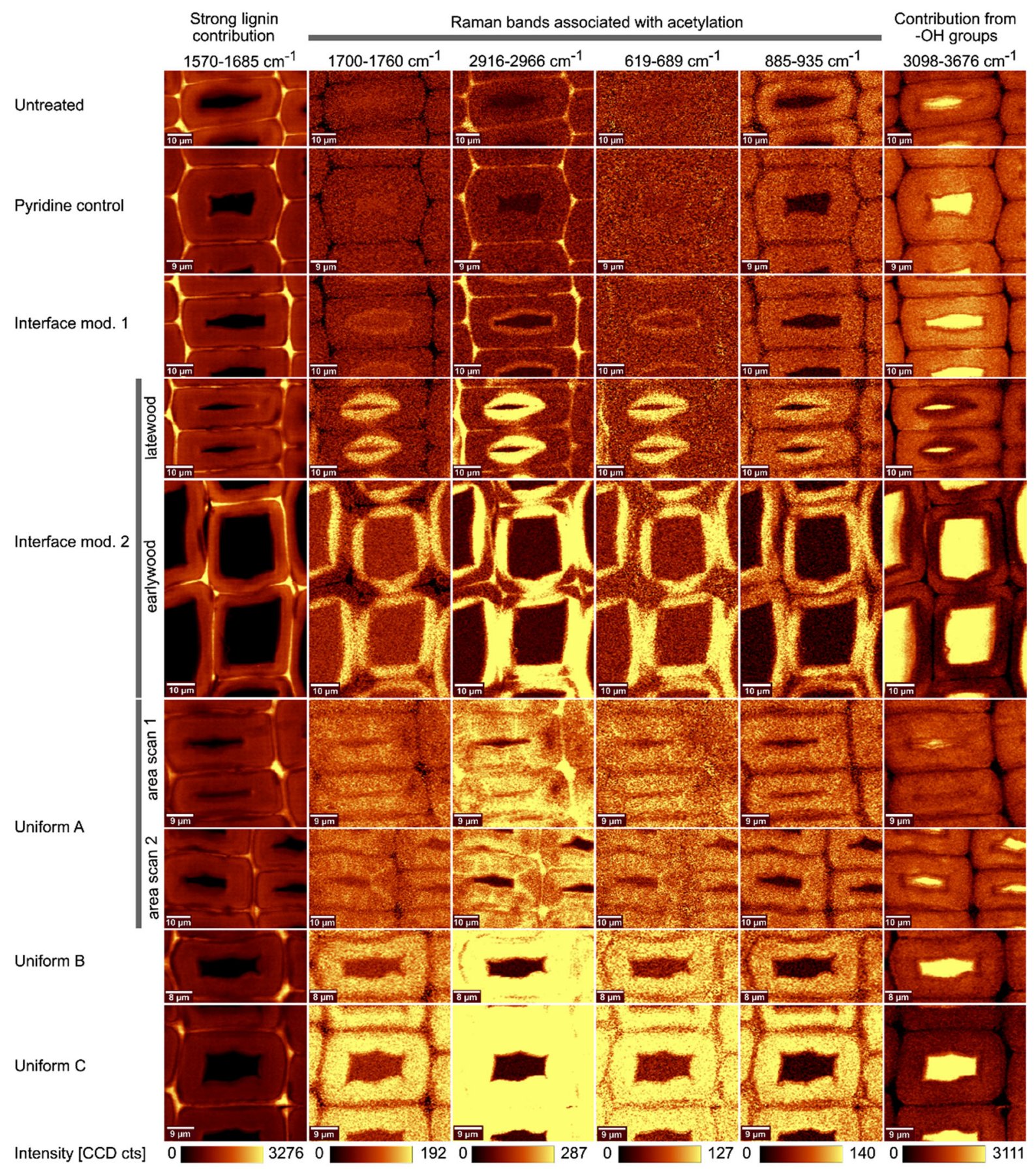

Fig. 3 Raman images of untreated and modified wood cross sections obtained by integrating over defined wavenumber areas. Column 1: aromatic lignin band at $1570-1685 \mathrm{~cm}^{-1}$, column 2: $\mathrm{C}=\mathrm{O}$ stretching at $1700-1760 \mathrm{~cm}^{-1}$, column 3 : $\mathrm{C}-\mathrm{H}$ stretching at $2916-2966 \mathrm{~cm}^{-1}$, column $4: \mathrm{O}-\mathrm{C}=\mathrm{O}$ deformation at $619-689 \mathrm{~cm}^{-1}$, column 5: $\mathrm{HCC}$ and $\mathrm{HCO}$ bending at $885-935 \mathrm{~cm}^{-1}$ and column 6: $\mathrm{OH}$ stretching at $3098-3676 \mathrm{~cm}^{-1}$. The intensity scale is the same for all images pertaining to the same bond 


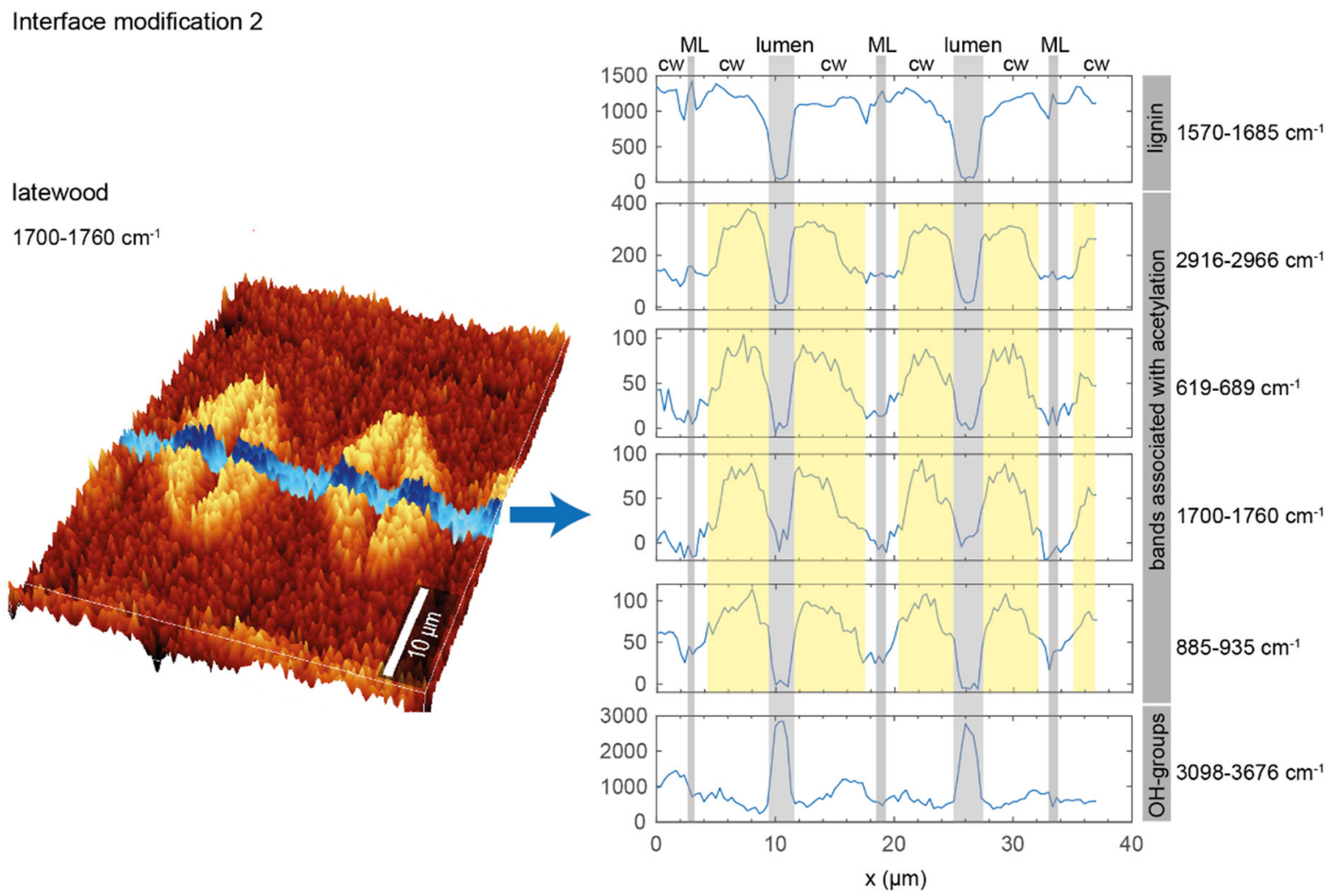

Fig. 4 3D visualisation of the $1700-1760 \mathrm{~cm}^{-1}$ band as well as profiles of this and the other evaluated bands through latewood cells, exposed to interface modification of the highest degree (interface modification 2). The approximate positions of middle lamellas (ML), lumina and cell wall (cw) along the specific cell wall section $(x)$ were estimated visually from the Raman image

(Figure S4), while the longer reaction time gave chemical changes traceable up to approximately $5 \mu \mathrm{m}$ both into the earlywood and latewood cell walls (Fig. 4, Figure S8). This indicates that the rate of acetic anhydride diffusion into the cell walls of earlywood and latewood was similar, but since earlywood has thinner cell walls than latewood, a higher proportion of earlywood cell walls was acetylated compared to latewood cell walls when subjected to the same treatment time. This has also been observed in recent studies (Awais et al. 2020; Mäkelä et al. 2021). Consequently, for interface modification of the highest degree, the diffusion fronts from adjacent earlywood cells often reached all the way to their common middle lamella, leading to its acetylation (Fig. 3-4), in line with previous observations (Rowell et al. 1994; Thybring et al. 2020b). The acetylation profile (depth of the interface of lignin signal (integration range, $1570-1685 \mathrm{~cm}^{-1}$ ) at the center of the $3 \mu \mathrm{m}$ wide band shown in the 3D Raman image. The yellow areas show approximate penetration depth for the acetylation. Corresponding data for earlywood cells are shown in Figure S8

modification) along lumen surfaces was, however, not uniform; the diffusion of acetic anhydride towards cell corners seemed to be more limited (Fig. 3-4), probably due to geometric dilution effects.

The protocol for uniform modification, where pyridine was used as a swelling agent, resulted in uniform acetylation of both earlywood (Figure S1) and latewood cell walls (Fig. 3, Figure S5-S7). An exception was, however, modification $\mathrm{A}$, where heavily acetylated strands were seen in the latewood cell walls, expanding radially from the lumina across cell walls layers (Fig. 3, Figure S5). We interpret these as cracks formed by pyridine swelling, which have provided easy access for acetic anhydride during the modification process.

Since water saturated specimens were imaged, the highest intensity from $\mathrm{OH}$ stretching vibrations was observed in the water-filled lumina (Fig. 3). The $\mathrm{OH}$ 


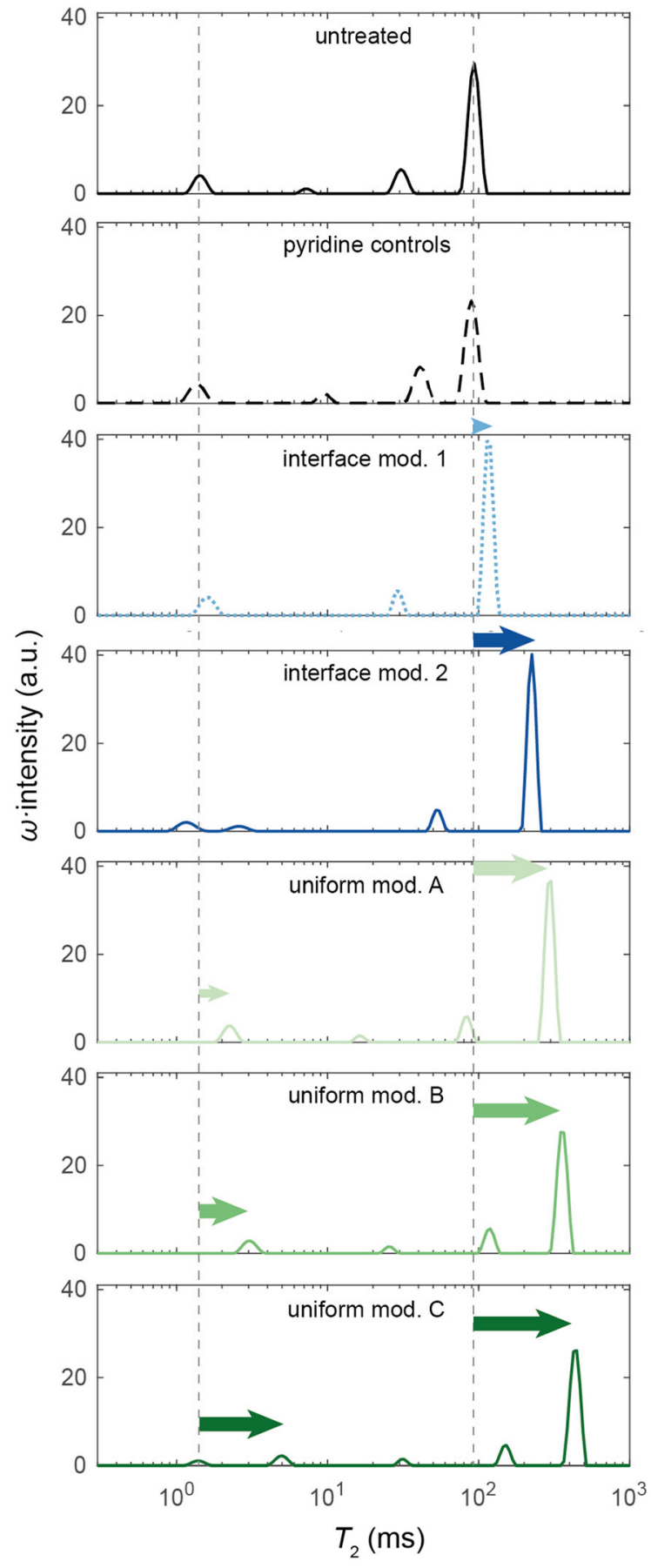

Fig. 5 Mean continuous $T_{2}$ distributions for the different specimen types. The vertical dashed lines indicate the $T_{2}$ for the maximum of the peaks representing water in cell walls and water in cell lumina, respectively, for the untreated wood signal was also strong from wood cell walls, where it originated from both water and wood cell wall biopolymers. Notably, the $\mathrm{OH}$ signal intensity was lower in the acetylated cell wall regions. In particular, this could be seen for the interface acetylation of the highest intensity for both latewood and earlywood cell walls (Fig. 3). The $\mathrm{OH}$ signal intensity decreased concurrently with increasing degree of modification also for the uniformly modified wood, i.e. the cell walls acetylated to a higher degree appear progressively darker in Fig. 3. This agreed with the hydroxyl accessibility measurements (Fig. 7), and the reduced $\mathrm{OH}$ signal could be caused by fewer $\mathrm{OH}$ groups within the wood cell wall material itself, or that these regions are less hydrated since the modification also reduced the moisture content (Fig. 6-7). Correspondingly, the cell walls of the pyridine controls appeared brighter and therefore more hydrated (Fig. 3), which also agrees with a higher cell wall moisture content for these samples in water saturated state (Fig. 6a).

For untreated as well as modified specimens, the hydroxyl accessibility was higher in latewood than in earlywood (Fig. 7a), which agrees with previous studies (Chow 1972; Thybring et al. 2020b). However, for the modified specimens, a larger difference between earlywood and latewood was seen especially for the interface modified samples. For the interface modification this is reasonable since the Raman imaging showed that the earlywood was modified to a higher degree than the latewood because of the thinner cell walls (Fig. 3). However, this seemingly larger difference between earlywood and latewood for the modified specimens may also, at least partly, be caused by the correction of the dry mass when calculating the $\mathrm{OH}$-accessibility. This correction was made using the mass increase obtained for both earlywood and latewood since the mass increase for earlywood and latewood separately was not known. Since earlywood cell walls were modified to a higher degree due to their thinner cell walls (Fig. 3), the $\mathrm{OH}-$ accessibility of earlywood is presumably underestimated while the $\mathrm{OH}$-accessibility of the latewood is presumably overestimated.

For the uniform modification, the cell wall moisture content decreased with increasing modification intensity (Fig. 6a) in accordance with previous studies (Beck et al. 2018b). However, apart from a reduction in cell wall moisture content, Fig. 6b shows a reduction in capillary water, i.e. water outside of cell walls. 
Water in cell walls
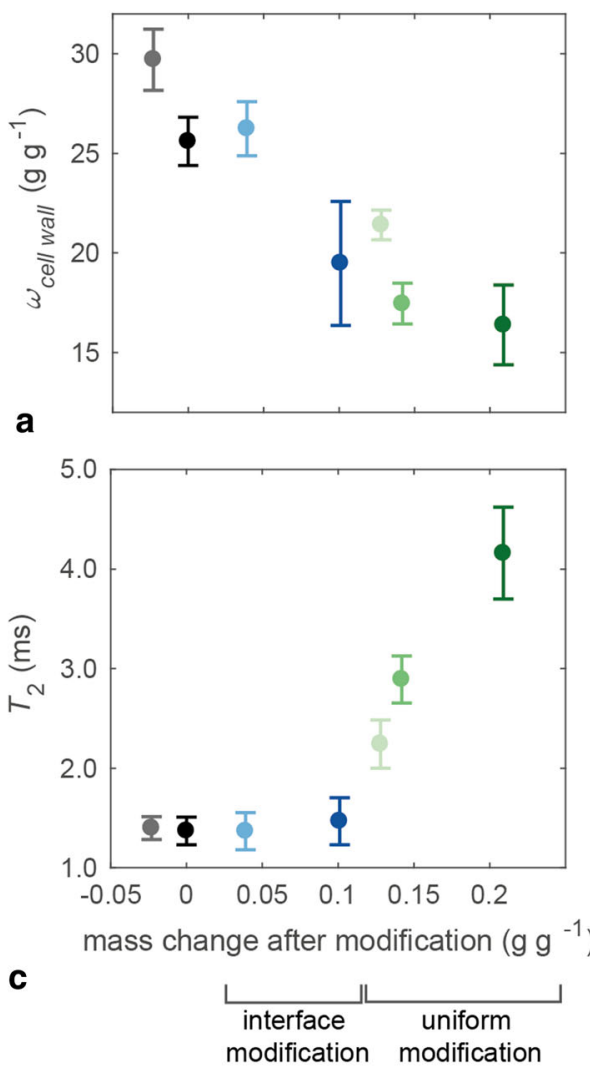

Capillary water

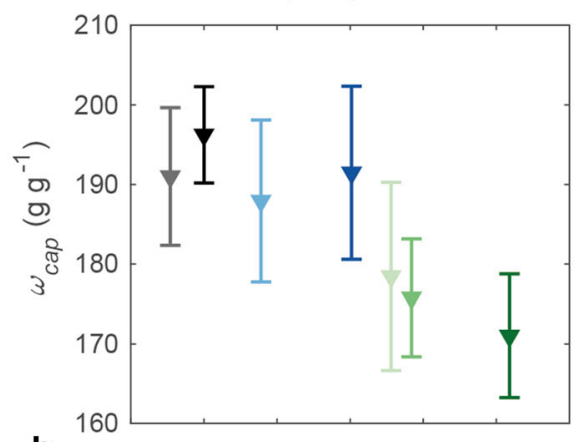

b

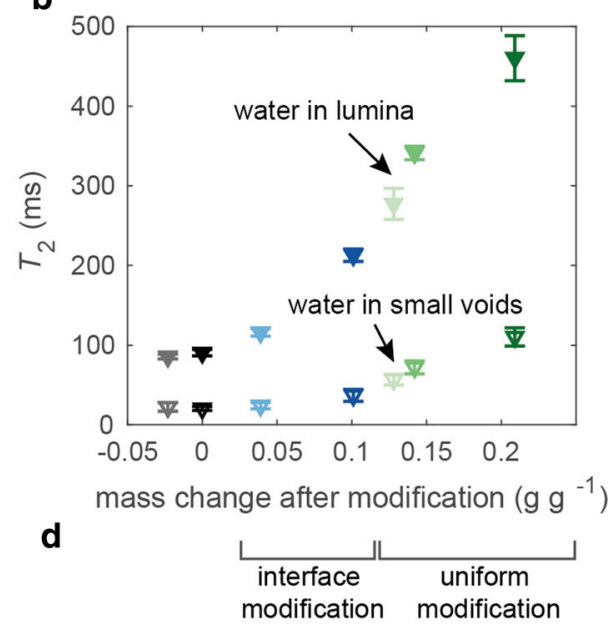

Fig. 6 Relaxation times $\left(T_{2}\right)$ and moisture contents in different parts of the wood structure evaluated from the LFNMR data. The two left panels (a and c) show moisture content and $T_{2}$ for water in cell walls while the two right panels (b and d) show moisture content and $T_{2}$ for capillary water outside cell walls. For the $T_{2}$, the capillary water has been further divided into water in cell lumina and water in small voids such as pit chambers. Note that in those cases where a certain water population is represented by more than one peak, the $T_{2}$ shown is the exponentially weighted average of the $T_{2}$ of the individual peaks. The error bars show the standard deviation

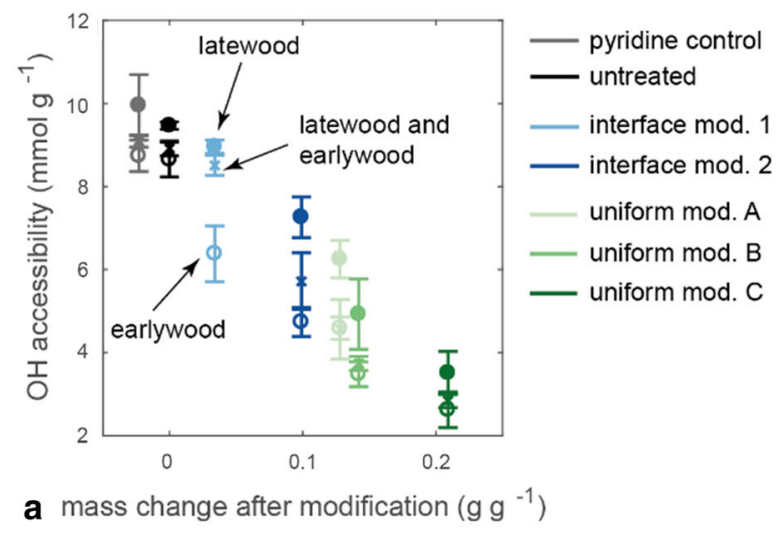

Fig. 7 a The average hydroxyl accessibility of the differently modified wood shown for samples consisting of only earlywood (open o) or latewood (filled o), as well as samples composed of both earlywood and latewood (x). b The moisture exclusion

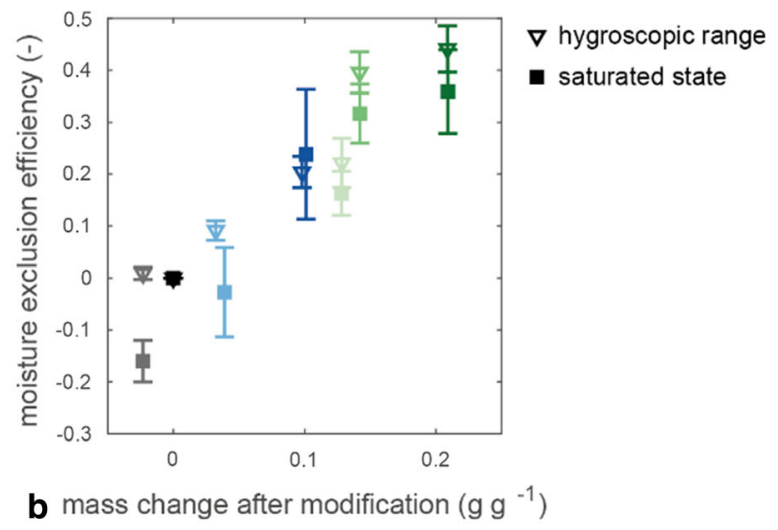

efficiency obtained from sorption balance measurements as well as from LFNMR measurements in saturated state. Error bars show the standard deviation 
This is most likely caused by a reduced lumen volume, primarily in latewood, because of the acetylation induced swelling of cell walls as observed by Sander et al. (2003). Note that evaluation of cell wall moisture contents from LFNMR measurements above $0{ }^{\circ} \mathrm{C}$ underestimates the absolute value of the cell wall moisture content (Beck et al. 2018b; Thybring et al. 2020a). Therefore, the absolute value of the cell wall moisture content in Fig. 6 should be interpreted with care, but differences between samples groups can still be evaluated.

The moisture exclusion efficiency in the hygroscopic moisture range generally increased with increasing modification intensity (Fig. 7b) and was similar in both desorption and absorption and at the different RH levels (Table S4). When evaluating the moisture exclusion efficiency based on the maximum cell wall moisture content from the LFNMR-data the same trend was seen (Fig. 7b). This supports that even though the cell wall moisture content is underestimated in LFNMR-measurements at room temperature (Beck et al. 2018b; Thybring et al. 2020a), it is still possible to compare different groups of specimens. One difference between the results in the hygroscopic range and in water saturated state was, however, that a slight reduction in moisture content and thus moisture exclusion efficiency was seen also for interface modification 1 in the hygroscopic range (Fig. 7b). This difference was, however, not seen in water saturated state (Fig. 7b).

\section{Conclusions}

By varying the conditions of the acetylation process it was possible to acetylate the cell wall-lumen interface only as well as control the depth of acetylation. For interface acetylation, the LFNMR measurements showed that the interaction between the wood and water in cell walls remained unchanged while the interaction with capillary water was altered. In addition, also the cell wall moisture content in saturated state remained unchanged for the interface modification of the lowest degree (interface modification 1). However, in the hygroscopic moisture range, a slight decrease in moisture content was seen. Likewise, a slight reduction in hydroxyl accessibility was observed for the earlywood for the same modification, but the total hydroxyl accessibility remained fairly unchanged. For the uniform modifications, the moisture content (in water saturated state and hygroscopic range) as well as the hydroxyl accessibility decreased with increasing modification intensity as expected.

Acknowledgments Sophie Füchtner is acknowledged for assistance with Raman microspectroscopy data evaluation and Stefan Backe is acknowledged for help with specimen preparation. Funding from the Swedish Research Council FORMAS, the Crafoord foundation, Interreg ÖresundKattegat-Skagerrak, the Royal Swedish Agricultural Academy and SNS Nordic Forest Research is gratefully acknowledged.

Funding Open access funding provided by Lund University. Funding was provided by the Swedish Research Council FORMAS grant numbers: 2018-00387 and 2017-00871, the Crafoord foundation, Interreg Öresund-Kattegat-Skagerrak, the Royal Swedish Agricultural Academy and SNS Nordic Forest Research.

Data availability Data are available in the supplemental material provided with this article.

\section{Declarations}

Conflict of interest The authors have no relevant financial or non-financial interests to disclose.

Open Access This article is licensed under a Creative Commons Attribution 4.0 International License, which permits use, sharing, adaptation, distribution and reproduction in any medium or format, as long as you give appropriate credit to the original author(s) and the source, provide a link to the Creative Commons licence, and indicate if changes were made. The images or other third party material in this article are included in the article's Creative Commons licence, unless indicated otherwise in a credit line to the material. If material is not included in the article's Creative Commons licence and your intended use is not permitted by statutory regulation or exceeds the permitted use, you will need to obtain permission directly from the copyright holder. To view a copy of this licence, visit http://creativecommons.org/licenses/by/4.0/.

\section{References}

Adebajo MO, Frost RL, Kloprogge JT, Kokot S (2006) Raman spectroscopic investigation of acetylation of raw cotton. Spectrochim Acta, Part A 64:448-453. https://doi.org/10. 1016/j.saa.2005.07.045

Alfredsen G, Flæte PO, Militz H (2013) Decay resistance of acetic anhydride modified wood: a review. Int Wood Prod J 4:137-143. https://doi.org/10.1179/2042645313Y. 0000000034

Alfredsen G, Pilgard A, Fossdal CG (2016) Characterisation of postia placenta colonisation during 36 weeks in acetylated southern yellow pine sapwood at three acetylation levels 
including genomic DNA and gene expression quantification of the fungus. Holzforschung 70:1055-1065. https:// doi.org/10.1515/hf-2016-0009

Almeida G, Gagné S, Hernández RE (2007) A NMR study of water distribution in hardwoods at several equlibrium moisture contents. Wood Sci Technol 41:293-307

Amiri A, Ottelin J, Sorvari J, Junnila S (2020) Cities as carbon sinks - classification of wooden buildings. Environ Res Lett 15:094076. https://doi.org/10.1088/1748-9326/ aba134

Angst V, Malo KA (2010) Moisture induced stresses perpendicular to the grain in glulam: review and evaluation of the relative importance of models and parameters. Holzforschung 64:609-617. https://doi.org/10.1515/hf.2010. 089

Araujo CD, Mackay AL, Hailey JRT, Whittall KP, Le H (1992) Proton magnetic resonance techniques for characterization of water in wood - application to white spruce. Wood Sci Technol 26:101-113

Awais M, Altgen M, Mäkelä M, Altgen D, Rautkari L (2020) Hyperspectral near-infrared image assessment of surfaceacetylated solid wood. ACS Appl Bio Mater 3:5223-5232

Beck G, Hegnar OA, Fossdal CG, Alfredsen G (2018a) Acetylation of Pinus radiata delays hydrolytic depolymerisation by the brown-rot fungus Rhondonia placenta. Int Biodeter Biodegr 135:39-52. https://doi.org/10.1016/j.ibiod.2018. 09.003

Beck G, Strohbusch S, Larnøy E, Militz H, Hill C (2017) Accessibility of hydroxyl groups in anhydride modified wood as measured by deuterium exchange and saponification. Holzforschung 72:17. https://doi.org/10.1515/hf2017-0059

Beck G, Thybring Emil E, Thygesen Lisbeth G, Hill C (2018b) Characterization of moisture in acetylated and propionylated radiata pine using low-field nuclear magnetic resonance (LFNMR) relaxometry. Holzforschung 72:225-233. https://doi.org/10.1515/hf-2017-0072

Bertero M, Boccacci P, Pike ER (1982) On the recovery and resolution of exponential relaxation rates from experimental data: a singular-value analysis of the laplace transform inversion in the presence of noise. Proc R Soc London Math Phys Sci 383:15-29. https://doi.org/10.1098/ rspa.1982.0117

Bock P, Gierlinger N (2019) Infrared and Raman spectra of lignin substructures: coniferyl alcohol, abietin, and coniferyl aldehyde. J Raman Spectrosc 50:778-792. https:// doi.org/10.1002/jrs.5588

Brischke C, Alfredsen G (2020) Wood-water relationships and their role for wood susceptibility to fungal decay. Appl Microbiol Biotechnol 104:3781-3795. https://doi.org/10. 1007/s00253-020-10479-1

Bryne LE, Wålinder MEP (2010) Ageing of modified wood. part 1: wetting properties of acetylated, furfurylated, and thermally modified wood. Holzforschung 64:295-304. https:// doi.org/10.1515/hf.2010.040

Chen K, Qiu H, Sun M, Lam F (2019) Experimental and numerical study of moisture distribution and shrinkage crack propagation in cross section of timber members. Constr Build Mater 221:219-231. https://doi.org/10.1016/ j.conbuildmat.2019.05.191
Chow SZ (1972) Hydroxyl accessibility, moisture content and biochemical activity in cell walls of Douglas fir trees. Tappi 55:539-544

Churkina $\mathrm{G}$ et al (2020) Buildings as a global carbon sink. Nat Sustain 3:269-276. https://doi.org/10.1038/s41893-0190462-4

Engelund ET, Thygesen LG, Svensson S, Hill CAS (2013) A critical discussion of the physics of wood-water interactions. Wood Sci Technol 47:141-161. https://doi.org/10. 1007/s00226-012-0514-7

Englund F, Bryne LE, Ernstsson M, Lausmaa J, Wålinder M (2009) Spectroscopic studies of surface chemical composition and wettability of modified wood. Wood Mat Sci Eng 4:80-85. https://doi.org/10.1080/17480270903337659

Forsman K, Serrano E, Danielsson H, Engqvist J (2020) Fracture characteristics of acetylated young Scots pine. Eur J Wood Wood Prod 78:693-703. https://doi.org/10.1007/ s00107-020-01548-3

Fredriksson M (2019) On wood-water interactions in the overhygroscopic moisture range-mechanisms, methods, and influence of wood modification. Forests 10:779

Fredriksson M, Thygesen LG (2017) The states of water in Norway spruce (Picea abies (L.) Karst.) studied by lowfield nuclear magnetic resonance (LFNMR) relaxometry: assignment of free-water populations based on quantitative wood anatomy. Holzforschung 71:77-90. https://doi.org/ 10.1515/hf-2016-0044

Fuchs W (1928) Zur kenntnis des genuinen lignins, i: die acetylierung des fichtenholzes. Ber Dtsch Chem Ges B 61:948-951

Gierlinger N, Keplinger T, Harrington M, Schwanninger M (2013) Raman imaging of lignocellulosic feedstock. In: van de Ven T, Kadla J (eds) Cellulose - biomass conversion. IntechOpen Limited, London

Glass SV, Boardman CR, Thybring EE, Zelinka SL (2018) Quantifying and reducing errors in equilibrium moisture content measurements with dynamic vapor sorption (DVS) experiments. Wood Sci Technol 52:909-927. https://doi. org/10.1007/s00226-018-1007-0

Glass SV, Boardman CR, Zelinka SL (2017) Short hold times in dynamic vapor sorption measurements mischaracterize the equilibrium moisture content of wood. Wood Sci Technol 51:243-260. https://doi.org/10.1007/s00226-016-0883-4

Hill CAS, Forster SC, Farahani MRM, Hale MDC, Ormondroyd GA, Williams GR (2005) An investigation of cell wall micropore blocking as a possible mechanism for the decay resistance of anhydride modified wood. Int Biodeter Biodegr 55:69-76. https://doi.org/10.1016/j.ibiod.2004.07. 003

Hill CAS, Jones D, Strickland G, Cetin NS (1998) Kinetic and mechanistic aspects of the acetylation of wood with acetic anhydride. Holzforschung 52:623. https://doi.org/10.1515/ hfsg.1998.52.6.623

Himmel S, Mai C (2015) Effects of acetylation and formalization on the dynamic water vapor sorption behavior of wood. Holzforschung 69:633. https://doi.org/10.1515/hf2014-0161

Istratov AA, Vyvenko OF (1999) Exponential analysis in physical phenomena. Rev Sci Instrum 70:1233-1257. https://doi.org/10.1063/1.1149581 
Keplinger T, Cabane E, Chanana M, Hass P, Merk V, Gierlinger N, Burgert I (2015) A versatile strategy for grafting polymers to wood cell walls. Acta Biomater 11:256-263. https://doi.org/10.1016/j.actbio.2014.09.016

Labbé N, De Jéso B, Lartigue JC, Daudé G, Pétraud M, Ratier M (2006) Time-domain ${ }^{1} \mathrm{H}$ NMR characterization of the liquid phase in greenwood. Holzforschung 60:265-270. https://doi.org/10.1515/hf.2006.043

Lawson C, Hanson R (1974) Linear least squares with linear inequality constraints solving least squares problems. Prentice-Hall Inc., Englewood Cliffs, New Jersey

Mantanis GI (2017) Chemical modification of wood by acetylation or furfurylation: a review of the present scaled-up technologies. BioResources 12:4478-4489

Mantanis GI, Young RA, Rowell RM (1994) Swelling of wood. Part II. Swell Org Liq Holzforschung 48:480-490

Menon RS, Mackay AL, Hailey JRT, Bloom M, Burgess AE, Swanson JS (1987) An NMR determination of the physiological water distribution in wood during drying. J Appl Polym Sci 33:1141-1155. https://doi.org/10.1002/app. 1987.070330408

Moghaddam MS, Wålinder M, Claesson P, Swerin A (2015) Wettability and swelling of acetylated and furfurylated wood analyzed by multicycle Wilhelmy plate method. Holzforschung 70:69-77. https://doi.org/10.1515/hf-20140196

Mäkelä M, Altgen M, Belt T, Rautkari L (2021) Hyperspectral imaging and chemometrics reveal wood acetylation on different spatial scales. J Mater Sci 56:5053-5066. https:// doi.org/10.1007/s10853-020-05597-0

Passarini L, Zelinka SL, Glass SV, Hunt CG (2017) Effect of weight percent gain and experimental method on fiber saturation point of acetylated wood determined by differential scanning calorimetry. Wood Sci Technol 51:1291-1305. https://doi.org/10.1007/s00226-017-09630

Popescu C-M, Hill CAS, Curling S, Ormondroyd G, Xie Y (2014) The water vapour sorption behaviour of acetylated birch wood: how acetylation affects the sorption isotherm and accessible hydroxyl content. J Mater Sci 49:2362-2371. https://doi.org/10.1007/s10853-013-7937$\mathrm{x}$

Ramsden MJ, Blake FSR, Fey NJ (1997) The effect of acetylation on the mechanical properties, hydrophobicity, and dimensional stability of Pinus sylvestris. Wood Sci Technol 31:97-104. https://doi.org/10.1007/BF00705925

Rayner ADM, Boddy L (1988) Fungal decomposition of wood: its biology and ecology. Wiley, Chichester, UK

Ringman R, Beck G, Pilgård A (2019) The importance of moisture for brown rot degradation of modified wood: a critical discussion. Forests 10:522

Ringman R, Pilgård A, Brischke C, Richter K (2014) Mode of action of brown rot decay resistance in modified wood: a review. Holzforschung 68:239. https://doi.org/10.1515/hf2013-0057

Ringman R, Pilgård A, Brischke $\mathrm{C}$, Windeisen $\mathrm{E}$, Richter $\mathrm{K}$ (2017) Incipient brown rot decay in modified wood: patterns of mass loss, structural integrity, moisture and acetyl content in high resolution. Int Wood Prod J 8:172-182. https://doi.org/10.1080/20426445.2017.1344382

Rowell RM (2006) Acetylation. Forest. Prod J 56:4-12

Rowell RM, Simonson R, Hess S, Plackett DV, Cronshaw D, Dunningham E (1994) Acetyl distribution in acetylated whole wood and reactivity of isolated wood cell-wall components to acetic anhydride. Wood Fiber Sci 26:11-18

Sander C, Beckers EPJ, Militz H, van Veenendaal W (2003) Analysis of acetylated wood by electron microscopy. Wood Sci Technol 37:39-46. https://doi.org/10.1007/ s00226-002-0160-6

Schmidt O (2006) Wood and tree fungi: biology, damage, protection and use. Springer Verlag, Berlin

Telkki VV, Yliniemi M, Jokisaari J (2013) Moisture in softwoods: fiber saturation point, hydroxyl site content, and the amount of micropores as determined from NMR relaxation time distributions. Holzforschung 67:291-300. https://doi. org/10.1515/hf-2012-0057

Thybring EE (2013) The decay resistance of modified wood influenced by moisture exclusion and swelling reduction. Int Biodeter Biodegr 82:87-95. https://doi.org/10.1016/j. ibiod.2013.02.004

Thybring EE, Digaitis R, Nord-Larsen T, Beck G, Fredriksson M (2020a) How much water can wood cell walls hold? A triangulation approach to determine the maximum cell wall moisture content. PLoS ONE 15:e0238319. https://doi.org/ 10.1371/journal.pone.0238319

Thybring EE, Piqueras S, Tarmian A, Burgert I (2020b) Water accessibility to hydroxyls confined in solid wood cell walls. Cellulose 27:5617-5627. https://doi.org/10.1007/s10570020-03182-X

Thygesen LG, Elder T (2008) Moisture in untreated, acetylated, and furfurylated Norway spruce studied during drying using time domain NMR. Wood Fiber Sci 40:309-320

Thygesen LG, Engelund ET, Hoffmeyer P (2010) Water sorption in wood and modified wood at high values of relative humidity. part i: results for untreated, acetylated, and furfurylated Norway spruce. Holzforschung 64:315-323. https://doi.org/10.1515/hf.2010.044

Wiley JH, Atalla RH (1987) Band assignments in the Ramanspectra of celluloses. Carbohyd Res 160:113-129. https:// doi.org/10.1016/0008-6215(87)80306-3

Williams DR (1995) The characterisation of powders by gravimetric water vapour sorption. Int LABMATE 20:40-42

Yang T, Thybring EE, Fredriksson M, Ma E, Cao J, Digaitis R, Thygesen LG (2020) Effects of changes in biopolymer composition on moisture in acetylated wood. Forests 11:719

Zabel RA, Morell JJ (1992) Wood microbiology: decay and its prevention. Academic Press, San Diego

Publisher's Note Springer Nature remains neutral with regard to jurisdictional claims in published maps and institutional affiliations. 